\title{
Examining the Relationships between Ethical Issues in Franchising Business Success and Characteristics of Franchising Businesses: A Study in Turkey
}

Musa Pinar*

Valparaiso University

\author{
Michael K. McCuddy** \\ Valparaiso University
}

\author{
Zeliha Eser*** \\ Başkent University
}

\begin{abstract}
Franchising offers growth opportunities for firms operating in global markets; however, cultural differences and national regulations in new markets can create ethical challenges and conflicts that could impact the success of franchising operations. Also, franchisors and franchisees have ethical obligations toward each other that must be properly managed for a mutually beneficial franchising relationship to exist. This study builds on earlier work that identified clusters of ethical issues that, from the perspective of franchisees in Turkey, are important for the long-term success of both franchisorfranchisee relationships and the franchising system in Turkey. In this paper, the earlier work is extended by examining the impact of six different franchising characteristics on the perceived importance of ethical issues in long-term franchising business success. The paper also discusses the implications of these findings for successful relationships between franchisors and franchisees.
\end{abstract}

Keywords: international franchising, franchising relationships, ethical issues and conflicts, franchising characteristics, Turkey.

\section{Franchising İşletmelerinin Başarıları ve Franchising İşletmelerinin Özellikleri Arasında Etik Konular İlişkisinin İncelenmesi: Türkiye'de Bir Çalışma}

\section{Özet}

Franchising küresel pazarlarda faaliyet gösteren işletmelere büyüme olanakları sunmakta, fakat yeni pazarlardaki kültürel farkl1lıklar ve ulusal düzenlemeler, franchising işletmesinin başarısını etkileyebilecek etiksel mücadelelere ve çatışmalara neden olabilmektedir. Aynı zamanda, franchisorların ve franchiselerin birbirlerine karsi etik sorumlulukları vardır ve karşılıklı faydalı franchising ilişkisi icin bunun düzgün bir şekilde

\footnotetext{
* Musa Pinar is a Professor in the College of Business at Valparaiso University, Valparaiso, Indiana, USA. E-mail: musa.pinar@valpo.edu

** Michael K. McCuddy is a Professor emeritus at Valparaiso University, Valparaiso, Indiana, USA. E-mail: Mike.McCuddy@valpo.edu

*** Zeliha Eser is a Professor in the Faculty of Business Administration at Başkent University, Ankara, Turkey. E-mail: zeser@baskent.edu.tr
} 
yönetilmesi gerekir. Bu araştırma, Türkiye'de franchisee bakış açısıyla belirlenen ve franchiser-franchise ilişkisinde ve Türkiye'de franchising sisteminde uzun vadeli başarı için önemli olan etik konular kümesini belirlemeye yönelik daha önceki bir çalışmanın temeline dayanmaktadır. Çalışmada, uzun vadede franchising işletmesinin başarısında, altı farklı franchising özelliğinin etik konuların algılanması üzerindeki etkisinin incelenmesiyle daha önce yapılan çalışma genişletilmektedir. Ayrıca franchiser ve franchise arasında başarılı bir ilişki için bulgular ve sonuçlar tartışılmaktadır.

Anahtar kelimeler: uluslararası franchising, franchising ilişkisi, etik konular ve çatışma, franchising özellikleri, Türkiye.

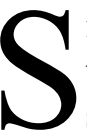

ince the 1950s, franchising has become a very popular means for rapid organizational growth in the United States and has been widely recognized as an important source of entrepreneurial activity for US businesses. As a result, modern franchising has enjoyed tremendous growth for many American companies such as McDonald's, Coca-Cola, Dunkin’ Donuts, Pizza Hut, Midas Mufflers, Holiday Inn, and others (Hall and Dixon, 1988; Storholm and Scheuing, 1994). In fact, it is estimated that, at the end of 2000, franchising represented about 40 to $50 \%$ of the US retail business (Swartz, 2001; Welsh et al. 2006), confirming that the franchising system is the dominant mode of retailing in the US. Also, as recent developments and changes in the global business environment have created new opportunities for firms in numerous industries to grow and expand their operations, franchising seems to be well-suited to take advantage of these growth opportunities. In addition, franchising provides an opportunity for firms to form global strategic alliances to grow and expand their businesses in developing and emerging markets. As a result of recent growth in both domestic and global markets, franchising has become a major channel in retail marketing, exerting a significant impact upon consumer buying decisions. The restaurant and fast food industry, various services, and non-food retailing have been the main business sectors for global growth (Hoffman and Preble, 2004).

In recent years, franchising is one of the rapidly growing industrial sectors in Western economies, and this rapid growth also applies to Europe and the UK (Rahatullah and Raeside, 2008) as well to Australia (Weaven et al. 2010). This convincingly shows the relevance of franchising and its evolution in the field of commercial distribution (Rondan-Cataluna et al., 2012) in different markets. The global expansion of franchising indicates that it is a "transferable" concept enabling many businesses to adapt to different cultures and business regulations around the globe (Amos, 2001). However, Shane (1996) states that franchising may require a different set of capabilities to be successful in these different situations. This suggests that while franchising offers growth opportunities for firms in global markets, cultural differences and national regulations in these new markets could pose some challenges for the success of franchising operations. In this regard, research shows that royalty taxes, contract laws, and the lack of specific franchise legislation are major issues about which franchisors and franchisees must be aware in the new global markets (Hoffman and Preble, 2004). Additionally, 
Larson (2002) points out the importance of legal, socio-cultural, and ethical issues for companies when they expand franchising internationally. Taken together, the above issues indicate that franchisees may not be guaranteed success when they enter into an agreement with the franchisor; nor are franchisors guaranteed ongoing success because they have developed a concept that has been accepted in the marketplace and has potential for expansion through the development of a franchisee network.

There is no doubt that franchisors and franchisees could face different ethical issues and/or conflicts during their relationships. While the conflicts are not uncommon in franchising relationships in the global marketplace, Weaven et al. (2010) assert that franchisor-franchisee conflict is not only inevitable, but also a necessary part of a dynamic business relationship. However, if these conflicts are effectively resolved, this can help both parties operate successfully, and if not effectively resolved, could destroy the franchising business. Thus, within the franchising context conflict may culminate in substantial disputation between franchisors and franchisees (Weaven et al., 2010). According to Storholm and Scheuing (1994), several fundamental areas of conflict could undermine the success of the franchising system; therefore, they recommend that these conflicts need to be resolved to the mutual satisfaction of both franchisors and franchisees. Otherwise, these conflicts could manifest themselves in unethical behaviors that could harm the franchising system. Moreover, as a unique form of business relationship, franchising imposes ethical obligations upon the two participants - the franchisor and the franchisee - toward each other so as to maintain a successful long-term franchising system and partnership. We believe that understanding the major ethical issues that are essential for creating a successful franchising system not only could minimize the potential conflicts between the franchisors and franchisees, but also could help to create a mutually beneficial business partnership.

The main focus of this study is to explore how franchising characteristics and the nature of relationships between franchisors and franchisees could influence the longterm performance and success of the franchising system. Potentially, such factors as the education and training offered by the franchisor, annual meetings with the franchisor, the franchisor brand, the industry in which the franchise operates, and the length of the franchising agreement could have an impact on ethical issues in the franchising system and on the long-term performance and success of franchising relationships. Studying the potential effects of these factors on franchising success could help franchisors and franchisees to address these ethical issues more effectively in order to build and maintain a mutually beneficial relationship. Moreover, most prior franchising research has focused primarily on the concerns of franchisors (Dant, 2008), whereas the franchisees' perspectives have just recently received increased attention (Grunhagen and Mittelstaedt, 2005; Weaven and Frazer, 2003). Understanding franchising issues - including those that are ethics-related - from the franchisees' perspective could provide different insights into the success of franchising systems.

While franchising has been very successful in the U.S. and other developed nations, it also can work advantageously in such developing transitional economies as the Czech Republic, Hungary, and Slovenia (Hoffman and Preble, 2004). Franchising 
can be successful in Turkey as well because the franchising system provides the necessary structure and support that otherwise would not be available (Chapman, 1997). In Turkey, franchising began in the 1960s with intercity passenger transportation, wherein gasoline stations sold bus tickets for travel to different cities. Today, Turkish franchising applications are commonly seen in various sectors, such as skin care products, apparel, fast food, cleaning, car rental, chocolate, office stationary products, real estate, publishing, communication, music markets, cargo, do-it-yourself stores, cosmetics, and automotive products (Kumkale, 2006). Although franchising is a fairly new business concept in Turkey, it has been growing very fast (Aydın, 2008). Since Turkey is one of the emerging markets of the world, the results of this study provide an opportunity to understand the importance of ethical issues for the long-term success of franchising in an emerging market.

\section{Background on Franchising and Ethical Considerations}

Franchising is described as a business opportunity wherein the owner (producer or distributor) of a business or a trademarked product grants exclusive rights to an individual for local distribution and/or sale of the service or product, and receives, in return, a royalty payment and conformance to certain quality standards and standardized levels of service to customers (Storholm and Scheuing, 1994). In this regard, franchising is an attractive organizational form for franchisors to pursue domestic and global growth strategies (Cochet et al., 2008). On the other hand, franchisees often choose the franchise option in order to become their own boss and run a business according to their own decisions while profiting from a proven business concept (Elango and Fried, 1997; Peterson and Dant, 1990). It is clear that a number of benefits of franchising exist for both the franchisor and the franchisee; however, Storholm and Scheuing (1994) assert that there are fundamental areas of conflict and that how these conflicts are resolved determines the success or failure of the franchise operation. Also, Waeven et al. (2010), who conducted a study to identity the major causes of franchising conflict, found that a lack of due diligence is associated with the formation of unrealistic expectations which, in turn, increase the potential for future relational conflict.

It is clear that franchising offers an important growth opportunity for firms to expand their businesses domestically and globally. However, as franchising has become a global phenomenon in a rapidly evolving environment, Preble and Hoffman (1999) assert that there is a need to control the franchising relationship and any potential ethical issues/conflicts with some form of ethical code. While governmental regulations could provide a solution to these ethical or conflict issues, Preble and Hoffman (1999) suggest that a code of ethics developed by a franchise association would be preferable for more closely controlling the manner in which franchise relationships are established. A code of ethics is defined as a set of rules and regulations founded on principles and ethical values that tend to prescribe behaviors (Kaptein and Schawartz 2008) which may be classified into two main categories of individual orientation and collective orientation (Gamez-Gonzalez et al. 2010). 
Based on a study covering 13 ethical policy areas of international ethical codes that covered 21 franchising activities in 21 countries, Preble and Hoffman (1999) identified several underlying ethical themes that should be included in a franchising association code of ethics. These ethical themes are good faith behavior, full disclosure, maintaining system integrity, avoiding deception, fairness, open communication, and safeguarding the public interest. Also, Randon-Cataluna et al (2012) suggest that an ethical code should be serious, comprehensive and compulsory for association members, allowing the association to achieve a high reputation to provide security and confidence to franchisees, and to be binding to all parties. Since franchising grows by attracting other entrepreneurs to join the system and to provide goods/services in their local market area, the ethical policies of "full disclosure" and "avoiding deception" are directed at efforts to attract franchisees. Moreover, Gamez and Gonzalez et al. (2010) state that ethical codes provided by franchising associations are essential for the evolution of franchising businesses if the goal is the promotion and spread of franchising. They further point out that a good ethical code may improve the trust of franchisees because it constitutes a guarantee for the franchise and current and potential franchisees.

Storholm and Scheuing (1994) indicate that the proliferation of franchise operations can best be appreciated by analyzing both the franchisor's and franchisee's motives. For example, while most franchisees seem to be concerned with the inequality of power in the franchise agreement, which is drawn up by the franchisor, franchisors complain most frequently of the tendency of many franchisees to operate on a continuing basis that violates various stipulations in the franchise agreement (Storholm and Scheuing, 1994). Moreover, according to Storholm and Scheuing (1994), since the franchisor prepares the franchise agreement to serve as the basis of the relationship, an asymmetrical distribution of power exists, resulting in opportunistic behavior by the franchisor. They also claim that, in other cases, questionable or unethical practices by franchisees likewise result in conflict. On the other hand, Eser (2013) indicates that trust between franchisor and franchisee is another important issue regarding co-operation, transaction cost, and satisfaction. This is also emphasized by Davies et al. (2011) with respect to the reciprocating role that trust plays between franchisee and franchisor in reducing opportunism and building a beneficial relationship.

According to Storholm and Scheuing (1994), franchisees perceive franchisors to be responsible for generating the following major sources of conflict: dual distribution implications; redirection/termination of the franchise agreement; full-line forcing or the requirement to purchase standardized products from the franchisor; questionable use of advertising revenues; and the asymmetrical nature of the franchise agreement. On the other hand, franchisors perceive that franchisees generate the following major sources of conflict: release of proprietary information to outside parties; non-payment or 'short' payment of royalties; and refusal of franchisees to adhere to standardized conditions in the franchise agreement. Also, a research by Weaven et al. (2010) indicates that the commonly cited problems for conflict include insufficient management experience, sub-optimal product procurement and supply, lack of provided financial assistance on supplies, the use of unsuitable support staff, and inappropriate royalty and advertising 
charges. Similarly, Rahatullah and Raeside (2008) identified actions of franchisors and franchisees which raise conflicts that could have potential consequences for the franchising relationship itself and for the long-term success of the franchising relationship. There is no doubt that any of the above areas could cause a conflict between the franchisor and franchisees - and if not resolved effectively, these conflicts could potentially destroy the franchising business.

The need for resolution of these ethical issues and conflicts can be understood in the context of agency theory, which, as Doherty and Alexander (2006) indicate, has been applied successfully to domestic franchising and more recently to international retail franchising. Agency theory suggests that the franchisor/franchisee relationship parallels that of the principal/agent relationship, where one party (the principal) delegates work to another party (the agent) who performs the work on a daily basis (Doherty and Quinn, 1999). Doherty and Alexander (2006) point out that a fundamental aspect of the principal/agent relationship is the contract between the parties which controls the agent's potential for moral hazard in that the agent may potentially use his/her knowledge to the detriment of the principal. They state that the potential for moral hazard arises because of the asymmetrical information between principal and agent - or in this case, the franchisor and the franchisee. Given the potential for moral hazard, the franchise contract, coupled with royalty payments and fees, are deemed to be fundamental methods by which the franchisor maintains power and control in the franchise relationship (Quinn and Doherty, 2000). In the final analysis, franchising imposes ethical obligations on the two participants - the franchisor and the franchisee - toward each other. This creates many ethical issues within the franchisor/franchisee relationship that, if effectively resolved, can help both parties operate successfully, and if not effectively resolved, could destroy the franchising business.

\section{Focus of the Study}

Since most prior franchising research has focused primarily on concerns of franchisors (Dant, 2008) and the franchisees' perspectives have just started receiving attention (Grunhagen and Mittelstaedt, 2005; Weaven and Frazer, 2003), examining ethical issues from the franchisees' perspective could provide different, yet very beneficial, insights into franchising relationships. Understanding the franchisees' perspectives on the ethical issues could be important in building trust between franchisors and franchisees, and could help to maintain system integrity and open communication (Thorelli, 1986). This, in turn, could be instrumental for the long-term success of the franchising system. Therefore, the central focus of this paper is to examine ethical issues in franchising from the perspective of franchisees. Specifically, we seek to ascertain how, if at all, certain characteristics of franchising affect franchisees' perceptions of the importance of various ethical issues in promoting and protecting the long-term interests of both the franchisor and the franchisee. To the best of our knowledge, there is no prior research that has examined the impact of the franchising characteristics on their perceptions of ethical issues in franchising; therefore, the results of this paper will begin to fill this void. 


\section{Methodology ${ }^{[1]}$}

The survey upon which this paper is based was designed to provide data for more than one study. The full survey, which can be obtained from the lead author, includes questions to address different topics and issues of interest to franchising businesses. However, only the survey questions that are relevant toşş this study are presented in Appendix A. These questions deal with (a) ethical issues in long-term franchising business success and (b) different characteristics of the franchising businesses in which the franchisees operate.

Responses to survey questions 1 through 14 in Appendix A deal with ethical issues in franchising business success. These 14 questions, which have been compiled from the literature, deal with ethics codes covered in global franchising agreements (Preble and Hoffman, 1999) and major sources of conflict for franchisors and franchisees (Storholm and Scheuing, 1994). Specifically, questions 1 and 6 are from Storholm and Scheuing (1994); questions 2, 4, and 8 through 14 are from Preble and Hofman (1999); and questions 3, 5, and 7 are covered by both Preble and Hofman (1999) and Storholm and Scheuing (1994). Since these 14 ethical issues were identified as the common policy topics in international ethical codes and/or as sources of conflict in franchising relationships, we believe that these questions are appropriate for examining ethical issues that are important in ensuring the long-term success of franchising businesses.

On questions 1 to 14 , the respondents were asked to indicate how important they considered each of the 14 ethical issues to be with respect to promoting and protecting the interests of both the franchisor and the franchisee in order to ensure the long-term success of the franchising business. A six-point Likert type scale that was designed using the Bass et al. (1974) method for approximating an interval level of measurement was employed with these questions. The response scale labels were as follows: $0=$ not at all important; 1 = slightly important; $2=$ important to some degree; $3=$ moderately important; 4 = very important; and 5 = extremely important. The responses to questions 1 through 14 serve as input into a factor analysis, which is intended to generate the importance of ethical issues measures used in this study. Also, the survey included questions related to the characteristics of the franchisees. As shown in Appendix A, the questions dealing with franchising characteristics are length of time as a brand franchisee, industry/sector of operations, national or international franchisor brand, length of current franchising agreement, whether or not education/training was provided upon signing a franchise agreement, and whether or not the franchisee has an annual meeting with the franchisor to discuss issues. These franchising characteristics served as the independent variables in the present study.

Since the survey instrument was originally developed in English, as recommended by Ball et al. (2002), it was translated into Turkish, and then it was later back-translated into English to avoid translation errors and to make sure that the intended meanings of the questions were maintained. The Turkish version of the instrument was pre-tested with several marketing and management faculty members in order to assure the ap-

[1] Since this paper is based on a survey that was designed to provide data for more than one study, the methodology presented in this paper is similar to the methodological discussions presented in two other papers. 
propriateness and consistency of the scale items. In addition, the survey instrument was pre-tested with eight franchisees to further assure that survey questions were clear regarding the wording or descriptions or measurement scales. Based on the feedback of these pre-tests, the instrument was further improved and refined.

\section{Sampling}

Although our general research interest is targeted toward ethical issues that are important in ensuring long-term business success for both franchisors and franchisees, the present study focuses specifically on the perceptions of franchisees regarding these ethical issues. Therefore, franchisees were used as sampling units. The survey was conducted in two major cities in Turkey: Ankara (the capital of Turkey and its second largest city) and Eskişehir (one of the major cities in Turkey). In order to determine the number of franchisees in these cities, we contacted UFRAD (Ulusal Franchising Derneği - National Franchising Association of Turkey). Although UFRAD did not provide us with a list of the franchisees in Ankara and in Eskişehir, the information provided by UFRAD (2010a, 2010b) indicated there were 300 franchisees in Ankara and 60 in Eskişehir when the study was conducted. This gave us a sampling frame of 360 franchisees; with the exception of gas stations, the majority of the franchise operations were located in major shopping malls. Also, UFRAD data (Aydın, 2008) shows that in Turkey $24 \%$ of the franchisees are in textiles, $27 \%$ in products, $16 \%$ in services, and $33 \%$ in apparel. Moreover the recent growth of the franchisees has been attributed to the opening of new shopping malls. Collectively, these informational items provided a reasonable indication of the distribution of franchisees by different industries as well as their locations, all of which served to guide our sampling. Our research showed that there were ten major shopping malls in Ankara and two shopping malls in Eskişehir.

Since there was no list of franchisees available in Ankara and Eskişehir from which to select samples, we were forced to use convenience sampling. However, in order to assure that various industries were included in the sample, we decided that convenience quota sampling would best serve the study's purpose. Since most of the franchisees were located in shopping malls (Aydın, 2008), researchers visited all tenshopping malls in Ankara and one shopping mall in EskişehirEskisehir to administer the survey. Also included in the study were franchised gas stations that were located outside of shopping malls. A total of 225 franchisees were visited from the 360 franchisees; of the 225 questionnaires that were distributed to franchisees in both cities, 189 were distributed to the franchisees at 11 shopping malls and 36 were distributed to gas stations. The questionnaire was collected at the end of the day that it was distributed. The data collection period lasted a little over three weeks. Out of 225 questionnaires distributed, 192 usable questionnaires were returned, yielding a response rate of $85 \%$. This response rate is very satisfactory given the heavy surveying activity that occurs in franchising businesses (Kaufmann and Dant, 2001). Based on information given to us by UFRAD (2010a, 2010b), our survey covers $53.3 \%$ of the franchises (192/360) in both cities. 


\section{Characteristics of the Franchise Businesses}

The franchising characteristics included in the survey are presented in Table 1. Concerning the receipt of education/training upon signing a franchising agreement, $47.9 \%$ of the respondents indicate they received such education/training and $52.1 \%$ of them did not receive it. Nearly the same proportion of respondents has an annual meeting with the franchisor to discuss franchising issues $(50.5 \%)$ as those who do not have such a meeting (49.5\%). Three-quarters of the businesses are national franchise brands and one-quarter are international franchise brands. In terms of the industry/sector of franchise operations, $31.8 \%$ of the respondents are in apparel, $20.3 \%$ are gas station operators, $16.7 \%$ are jewelers, $9.9 \%$ deal in appliances, $17.7 \%$ are in food and beverage operations, and $3.6 \%$ are in sporting operations. With respect to length of time as a brand franchisee, $27.1 \%$ were relative novices, being brand franchisees for 'one to two years'; $40.1 \%$ have been brand franchisees for 'three to five years'; and the remainder $(32.8 \%)$ have been brand franchisees for 'six years or more.' The vast majority of the franchising agreements run for a period of three or more years, with $44.8 \%$ being 'three to five years' and $42.2 \%$ being 'six years or more.'

\section{Results}

\section{Identifying Clusters of Ethical Factors for Franchising Business Success ${ }^{[2]}$}

Questionnaire items 1 through 14 were submitted to a factor analysis. As shown in Table 2, the factor analysis produced five distinct factors related to Ethical Issues in Franchising Business Success Factors with eigenvalues in excess of 1.0 (Haire et al., 2010 , p. 111). These five factors collectively accounted for $72.643 \%$ of the common variance. The factor loadings for each factor presented in Table 1 are greater than 0.50 and therefore are very significant, according to the criteria for a sample size of 150 or more (Haire et al., 2010, pp. 117-118). In order to evaluate the consistency of the items on each of the five factors, an internal consistency reliability analysis was conducted; Cronbach's alpha coefficients are shown in Table 2. Haire et al. (2010, p. 125) recommend a threshold level of .70 for an appropriate level of measurement reliability; however, they suggest that .60 is an acceptable threshold level in exploratory research.

As shown in Table 2, Cronbach's alpha was .830 for Factor 1, .700 for Factor 2, and .616 for Factor 4; all of which exceed the exploratory threshold level for acceptable reliability and two of which exceed the more rigorous threshold level. Cronbach's coefficient alpha was .586 for Factor 3 and .413 for Factor 5, both of which fall below the more liberal threshold level of .60 (Haire, et al., 2010: 125). However, coefficient alpha for Factor 3 is quite close to the .60 threshold level and the factor analysis results for both Factor 3 and Factor 5 have factor loadings that are very significant. Moreover, both Factor 3 and Factor 5 contain two survey items. Since Factor 3 and Factor 5 meet the factor loading and eigenvalue criteria, and given that the present scale development

[2] Since this paper is based on a survey that was designed to provide data for more than one study, the methodology presented in this paper is similar to the methodological discussions presented in two other papers. 
is exploratory and these two factors contain only two items each, we will use them with appropriate analytical caution - rather than abandon them due to the lower than desirable threshold reliability level. Thus, each factor is worthy of being used in further investigation - particularly since the present study can be considered to be exploratory research and this effort is an early attempt to develop useful scales of measurement for Ethical Issues in Franchising Business Success.

Table 1

\section{Demographic Characteristics of the Sample}

\begin{tabular}{|c|c|c|}
\hline Education/Training by Franchisor: & Frequency & Percent \\
\hline Yes & 92 & 47.9 \\
\hline No & 100 & 52.1 \\
\hline Annual Meeting with Franchisor to Discuss Issues: & Frequency & Percent \\
\hline Yes & 97 & 50.5 \\
\hline No & 95 & 49.5 \\
\hline \multicolumn{3}{|l|}{ Franchisor Brand: } \\
\hline National & 143 & 74.5 \\
\hline International & 49 & 25.5 \\
\hline Industry/Sector of Operations: & Frequency & Percent \\
\hline Apparel & 61 & 31.8 \\
\hline Gas Station & 39 & 20.3 \\
\hline Jeweler & 32 & 16.7 \\
\hline Appliances & 19 & 9.9 \\
\hline Food and Beverages & 34 & 17.7 \\
\hline Sporting & 7 & 3.6 \\
\hline Length of Time as Current Brand Franchisee: & Frequency & Percent \\
\hline 1 to 2 Years & 52 & 27.1 \\
\hline 3 to 5 Years & 77 & 40.1 \\
\hline 6 Years or More ${ }^{a}$ & 63 & 32.8 \\
\hline Length of Current Franchising Agreement: & Frequency & Percent \\
\hline 1 to 2 Years & 25 & 13.0 \\
\hline 3 to 5 Years & 86 & 44.8 \\
\hline 6 Years or More ${ }^{b}$ & 81 & 42.2 \\
\hline
\end{tabular}

"The category 'more than 10 years' contained only seven franchisee respondents; therefore, it was combined with the category of ' 6 to 10 years' to form a new category of '6 years or more.'

${ }^{b}$ Although the category 'more than 10 years' had 18 respondents, it was combined with the category '6 to 10 years' to parallel the approach used with the 'length of time as current brand franchisee' independent variable. 
Table 2

\section{Results of Factor Analysis on Ethical Issues in Franchising Business Success Factors}

\begin{tabular}{|c|c|c|c|c|c|c|}
\hline $\begin{array}{l}\text { Subscales for Issues Regarding Long-Term } \\
\text { Franchising Business Success }\end{array}$ & Means & $\begin{array}{l}\text { St. } \\
\text { Dev. }\end{array}$ & $\begin{array}{l}\text { Factor } \\
\text { Loading }\end{array}$ & $\begin{array}{l}\text { Eigen- } \\
\text { values }\end{array}$ & $\begin{array}{l}\text { variance } \\
\text { explained }\end{array}$ & Alpha \\
\hline EIFBS Factor 1: Ethical Culture & 3.67 & 0.701 & & 4.551 & 32.507 & 0.803 \\
\hline $\begin{array}{l}\text { Q11: Providing a quality product or service in } \\
\text { line with the image of franchising business. }\end{array}$ & 4.11 & 0.936 & 0.845 & & & \\
\hline $\begin{array}{l}\text { Q10: Providing open and effective two-way } \\
\text { communication among all parties. }\end{array}$ & 3.81 & 0.872 & 0.813 & & & \\
\hline $\begin{array}{l}\text { Q12: Practicing non-discrimination and af- } \\
\text { firmative action regarding all parties. }\end{array}$ & 3.45 & 0.849 & 0.771 & & & \\
\hline $\begin{array}{l}\text { Q14: Having a general statement promoting } \\
\text { ethical principles that are consistent with the } \\
\text { image of the franchising business. }\end{array}$ & 3.09 & 1.143 & 0.643 & & & \\
\hline Q8: Complying with all applicable laws. & 3.90 & 0.686 & 0.558 & & & \\
\hline EIFBS Factor 2: InformationIintegrity & 3.88 & 0.561 & & 2.030 & 14.503 & 0.700 \\
\hline $\begin{array}{l}\text { Q3: Providing a notice and process for dealing } \\
\text { with disputes, terminations, or expirations of } \\
\text { agreements. }\end{array}$ & 3.89 & 0.684 & 0.844 & & & \\
\hline $\begin{array}{l}\text { Q2: Providing full and accurate disclosure of } \\
\text { information when selling a franchise and after } \\
\text { the franchising agreement is signed. }\end{array}$ & 3.68 & 0.899 & 0.804 & & & \\
\hline $\begin{array}{l}\text { Q5: Avoiding questionable use of advertising } \\
\text { payments and/or having no false or misleading } \\
\text { advertising. }\end{array}$ & 4.08 & 0.484 & 0.595 & & & \\
\hline EIFBS Factor 3: Stakeholder Relationship & 3.59 & 0.693 & & 1.340 & 9.569 & 0.586 \\
\hline $\begin{array}{l}\text { Q9: Having fair dealings between franchisor } \\
\text { and franchisee. }\end{array}$ & 4.01 & 0.667 & 0.868 & & & \\
\hline Q13: Safeguarding the public interest. & 3.18 & 0.950 & 0.620 & & & \\
\hline EIFBS Factor 4: Franchising Integrity & 3.71 & 0.597 & & 1.182 & 8.440 & 0.616 \\
\hline $\begin{array}{l}\text { Q6: Having a franchise agreement that seems to } \\
\text { protect the franchisor more than the franchisee. }\end{array}$ & 3.79 & 0.715 & 0.873 & & & \\
\hline $\begin{array}{l}\text { Q4: Maintaining the integrity and reputation of } \\
\text { the franchise concept or system. }\end{array}$ & 3.62 & 0.690 & 0.710 & & & \\
\hline EIFBS Factor 5: Franchising Expansion & 3.57 & 0.459 & & 1.067 & 7.625 & 0.413 \\
\hline $\begin{array}{l}\text { Q1: Pursuing dual distribution opportunities for } \\
\text { the franchisor to increase sales for the franchis- } \\
\text { ing business. }\end{array}$ & 3.12 & 0.546 & 0.771 & & & \\
\hline $\begin{array}{l}\text { Q7: Protecting trade secrets or proprietary } \\
\text { information and not releasing proprietary infor- } \\
\text { mation to outside parties. }\end{array}$ & 4.02 & 0.609 & 0.728 & & & \\
\hline $\begin{array}{l}\text { EIFBS Overall Factor: Ethical Issues in } \\
\text { Franchising Business Success }\end{array}$ & 3.7 & 0.44 & & & & \\
\hline
\end{tabular}

Scale: $0=$ not at all important; $1=$ slightly important; $2=$ important to some degree; $3=$ moderately important; $4=$ very important; and 5 = extremely important 
Based on an analysis of the questionnaire items contained in each factor, the following Ethical Issues in Franchising Business Success factor labels were derived: (1) Factor 1 - issues concerning the development and maintenance of an ethical business culture for franchising, named as Ethical Culture; (2) Factor 2 - ethical issues concerning the integrity of franchising information, named as Information Integrity; (3) Factor 3 - ethical issues concerning the franchising system's key stakeholder relationships, named as Stakeholder Relationship; (4) Factor 4 - ethical issues concerning the integrity of the franchising system, named as Franchising Integrity; and (5) Factor 5 - ethical issues concerning the protection and expansion of franchising business opportunities, named as Franchising Expansion. The numerical value for each subscale is the arithmetic mean of the questionnaire items included in that subscale.

In addition to the five factors, an Ethical Issues in Franchising Business Success Overall Factor has been created by obtaining the arithmetic mean of the 14 ethical issues questionnaire items. The Overall Factor has a very high level of reliability as indicated by Cronbach's alpha of .831 .

\section{Relating the Clusters of Ethical Issues to Franchising Characteristics}

The central focus of this study concerns whether or not these clusters of ethical issues are related in any systematic way to various franchising characteristics. Six survey items provide information about franchising characteristics that are relevant to addressing this research question (see Appendix A and Table 1 for these franchising characteristics and their measurement levels). These six items are: 'length of time as a current brand franchisee' (Q15); 'industry/sector of operations' (Q16); 'franchisor brand' (Q17); 'length of current franchising agreement' (Q18); 'education or training upon signing a franchising agreement' (Q19); and 'annual meeting with the franchisor to discuss issues' (Q20). The franchising factors that are measured at two levels will be evaluated with the two independent samples $t$-test, and the factors measured at three or more levels will be analyzed with the Oneway ANOVA procedure.

\section{Franchising Characteristics with Two Levels}

Three of the franchising characteristics - receiving education/training from the franchisor (survey Q19), having an annual meeting with the franchisor (survey Q20), and the franchisor brand (survey Q17) - have two measurement levels. For each set of analyses, Table 3 shows the cell means, the significance level for the Levene test of equality of variances, the significance level for the $t$-test, and a summary statement regarding the significant comparison of means. The $p$-values for the $t$-tests reflect the testing procedure that is appropriate based on the results of the Levene test for equal or unequal cell variances. Based on the $t$-test results, significant differences between means exist in five of six comparisons for 'education/training from the franchisor', two of six comparisons for 'annual meeting with the franchisor,' and one of six comparisons for the 'franchisor brand.' Specifically, the results of the $t$-test comparisons indicate that franchisees who receive education/ training from the franchisor attribute a significantly greater level of importance to ethical issues in general (Overall Factor) as well as to 
ethical issues specifically concerning the development and maintenance of an Ethical Culture (Factor 1); the Information Integrity (Factor 2); the Franchising Integrity (Factor 4); and the Franchising Expansion (Factor 5). Franchisees who meet annually with their franchisor also attribute significantly greater importance to ethical issues concerning the information integrity (Factor 2) and the franchising system (Factor 4). With the exception of franchising expansion (Factor 5), whether franchisees are associated with national brands or international brands makes no difference in the perceived importance for the various groups of Ethical Issues in Franchising Business Success. Franchising expansion (Factor 5) is significantly more important for international brands than for national brands.

Table 3

Ethical Issues in Franchising Business Success Factors Relative to Franchising Characteristics with Two Levels

\begin{tabular}{|c|c|c|c|c|c|c|c|}
\hline $\begin{array}{r}\text { Q 19: Education/Training } \\
\text { from Franchisor: }\end{array}$ & $\mathbf{N}$ & $\begin{array}{c}\text { EIFSB } \\
\text { Overall } \\
\text { Factor }\end{array}$ & $\begin{array}{c}\text { Factor 1: } \\
\text { Ethical } \\
\text { Culture }\end{array}$ & $\begin{array}{c}\text { Factor } \\
\text { 2: Infor- } \\
\text { mation- } \\
\text { Integrity }\end{array}$ & $\begin{array}{c}\text { Factor } \\
\text { 3: Stake- } \\
\text { holder } \\
\text { Rela- } \\
\text { tionship }\end{array}$ & $\begin{array}{c}\text { Factor 4: } \\
\text { Fran- } \\
\text { chising } \\
\text { Integrity }\end{array}$ & $\begin{array}{c}\text { Factor 5: } \\
\text { Fran- } \\
\text { chising } \\
\text { Expan- } \\
\text { sion } \\
\end{array}$ \\
\hline 1. Yes - means & 92 & 3.84 & 3.91 & 4.01 & 3.65 & 3.81 & 3.66 \\
\hline 2. No-means & 100 & 3.56 & 3.46 & 3.77 & 3.54 & 3.62 & 3.49 \\
\hline$p$-value for Levene test & & .000 & .824 & .014 & .000 & .208 & .000 \\
\hline$p$-value for $t$-test & & .000 & .000 & .003 & .276 & .032 & .014 \\
\hline Significant mean comparison & & $1>2$ & $1>2$ & $1>2$ & None & $1>2$ & $1>2$ \\
\hline $\begin{array}{r}\text { Q 20: Annual Meeting with } \\
\text { Franchisor: }\end{array}$ & $\mathbf{n}$ & $\begin{array}{l}\text { EIFSB } \\
\text { overall } \\
\text { Factor }\end{array}$ & $\begin{array}{c}\text { Factor 1: } \\
\text { Ethical } \\
\text { Culture }\end{array}$ & $\begin{array}{c}\text { Factor } \\
\text { 2: Infor- } \\
\text { mation } \\
\text { Integrity }\end{array}$ & $\begin{array}{c}\text { Factor } \\
\text { 3: Stake- } \\
\text { holder } \\
\text { Rela- } \\
\text { tionship }\end{array}$ & $\begin{array}{c}\text { Factor 4: } \\
\text { Fran- } \\
\text { chising } \\
\text { Integrity }\end{array}$ & $\begin{array}{c}\text { Factor 5: } \\
\text { Fran- } \\
\text { chising } \\
\text { Expan- } \\
\text { sion }\end{array}$ \\
\hline 3. Yes - means & 97 & 3.74 & 3.68 & 3.97 & 3.56 & 3.80 & 3.63 \\
\hline 4. No-means & 95 & 3.66 & 3.67 & 3.79 & 3.63 & 3.61 & 3.51 \\
\hline$p$-value for Levene test & & .000 & .000 & .171 & .000 & .282 & .000 \\
\hline$p$-value for $t$-test & & .215 & .881 & .029 & .519 & .024 & .703 \\
\hline Significant mean comparison & & None & None & $1>2$ & None & $1>2$ & None \\
\hline Q 17: Franchisor Brand: & $\mathbf{n}$ & $\begin{array}{c}\text { EIFSB } \\
\text { Overall } \\
\text { Factor }\end{array}$ & $\begin{array}{c}\text { Factor 1: } \\
\text { Ethical } \\
\text { Culture }\end{array}$ & $\begin{array}{c}\text { Factor } \\
\text { 2: Infor- } \\
\text { mation } \\
\text { Integrity }\end{array}$ & $\begin{array}{c}\text { Factor } \\
\text { 3: Stake- } \\
\text { holder } \\
\text { Rela- } \\
\text { tionship }\end{array}$ & $\begin{array}{c}\text { Factor 4: } \\
\text { Fran- } \\
\text { chising } \\
\text { Integrity }\end{array}$ & $\begin{array}{c}\text { Factor 5: } \\
\text { Fran- } \\
\text { chising } \\
\text { Expan- } \\
\text { sion }\end{array}$ \\
\hline 1. National - means & 143 & 3.69 & 3.65 & 3.90 & 3.63 & 3.73 & 3.51 \\
\hline 2. International - means & 49 & 3.70 & 3.73 & 3.84 & 3.49 & 3.64 & 3.76 \\
\hline$p$-value for Levene test & & .172 & .298 & .070 & .188 & .990 & .005 \\
\hline$p$-value for $t$-test & & .810 & .537 & .580 & .225 & .375 & .003 \\
\hline Significant mean comparison & & None & None & None & None & None & $2>1$ \\
\hline
\end{tabular}




\section{Interactions between Education/Training, Annual Meetings and Franchise Brand}

The results in Table 3 indicate that the education/training offered by franchisors when signing the agreement has a significant effect on the perceived importance of all but one of the ethical issues investigated in this study for the long term success of franchising business. However, having annual meetings and the franchise brand being national or international does not seem to have a significant effect on the perceptions of these ethical issues. In order to gain some insights into whether there are any relationships or associations among these franchising characteristics of education/training provided by the franchisors, annual meetings, and the franchise being national or international brand, Chi-square tests using cross-tabulation analysis were conducted and the results are presented in Table 4. The Chi-square test in Panel A of Table 4 indicates a significant association between education/training and having an annual meeting $(p<.001)$. The cell frequencies indicate that franchisors who offer initial education/training are more likely to have annual meetings, whereas those franchisors who do not offer initial training are more likely not to offer an annual meeting. The results of the Chi-square test in Panel B of Table 4 show a significant association between education/training and franchisor brand $(p<.001)$, where a higher percentage of international franchisor brands offer initial education/training and a higher percentage of national franchisor brands do not offer initial education/training. Finally, the Chi-square results in Panel C of Table 4 indicate a significant association between an annual meeting and the franchisor brand $(p<.001)$. The cell frequencies suggest that while a higher percentage of the international franchisor brands have annual meetings, a higher percentage of national brands do not have annual meetings. The significant associations between these franchising characteristics may suggest an existence of interaction effects between them for the ethical issues identified in Table 2.

As shown in Table 3, there are significant main effects for the factors of having initial education/training, having annual meetings, and the franchisor brand being national or international. Also, the Chi-square test results in Table 4 offered some insights into the associations between these franchising characteristics. In addition to these tests, we conducted further analyses to determine if two-way and three-way interaction among these franchising characteristics had any significant effects on ethical issues in Table 2. The results in Table 5 show significant interaction effects between education/training (Q19) and having an annual meeting (Q20) for Overall Factor (ethical issues in general) $(F(1,184), p<.05)$, Ethical Culture (Factor 1) $(F(1,184), p<.01)$, Franchising Integrity (Factor 2$)(F(1,184), p<.05)$, and Franchising Integrity (Factor 4$)(F(1,184), p<.01)$, but no significant interactions for Stakeholder Relationship (Factor 3) and Franchising Expansion (Factor 5). The two-way interaction effect between the factors of having an annual meeting and the franchisor brand being national or international is significant for only Ethical Culture (Factor 1) and but not for other factors (see Table 5). Finally, the two-way interaction effect between initial training/education and franchisor brand and the three-way interaction effects among the factors of initial education/training, having annual meeting and franchisor brand are not significant for either the Overall Factor or any of the Factors. The significant interaction effects on the ethical issues indicate the 
importance of having both initial education/training and having annual meetings with regard to dealing with the ethical issues and the long-term success of the franchising business. Therefore, these results could have important managerial implications for establishing good ethical standards to reduce any potential conflicts that could adversely impact the success of franchising relationships.

Table 4

Examining the Associations between Education/Training, Annual Meeting and Franchise Brand

\begin{tabular}{|c|c|c|c|c|}
\hline \multicolumn{2}{|c|}{ Panel A } & \multicolumn{2}{|c|}{ Education/Training from Franchisor (Q19) } & \multirow[b]{2}{*}{ Total } \\
\hline & & Yes & No & \\
\hline \multirow{4}{*}{$\begin{array}{l}\text { Annual meeting } \\
\text { (Q20) }\end{array}$} & Yes & $\begin{array}{c}66 \text { (R: } 71.7 \%),(\mathrm{C}: \\
68 \%)\end{array}$ & $\begin{array}{c}31(\mathrm{R}: 62.2 \%) \quad(\mathrm{C}: \\
89.0 \%)\end{array}$ & $97(100 \%)$ \\
\hline & No & $\begin{array}{c}26(\mathrm{R}: 31.0 \%) \quad(\mathrm{C}: \\
32 \%)\end{array}$ & $\begin{array}{c}69 \text { (R: } 69.0 \%)(\mathrm{C}: \\
72.4 \%)\end{array}$ & $95(100 \%)$ \\
\hline & Total & $92(100 \%)$ & $100(100 \%)$ & 192 \\
\hline & \multicolumn{4}{|c|}{ Chi-square, $\mathrm{df}=1: 31.814, \mathrm{p}=.000$} \\
\hline \multicolumn{2}{|c|}{ Panel B } & \multicolumn{2}{|c|}{ Education/Training from Franchisor (Q19) } & \\
\hline & & Yes & No & Total \\
\hline \multirow{4}{*}{$\begin{array}{c}\text { Franchisor } \\
\text { Brand (Q17) }\end{array}$} & National & $\begin{array}{c}54 \text { (R: } 37.8 \%)(\mathrm{C}: \\
58.7 \%)\end{array}$ & $\begin{array}{c}89 \text { (R: } 62.2 \%),(\mathrm{C}: \\
89.0 \%)\end{array}$ & $143(100 \%)$ \\
\hline & International & $\begin{array}{c}38 \text { (R: } 77.6 \%)(\mathrm{C}: \\
41.3 \%)\end{array}$ & $\begin{array}{c}11 \text { (R: } 22.4 \%),(\mathrm{C}: \\
11.0 \%)\end{array}$ & $49(100 \%)$ \\
\hline & Total & $92(100 \%)$ & $100(100 \%)$ & 192 \\
\hline & \multicolumn{4}{|c|}{ Chi-square, $\mathrm{df}=1: 23.151, \mathrm{p}=.000$} \\
\hline \multicolumn{2}{|c|}{ Panel C } & \multicolumn{2}{|c|}{ Annual Meeting (Q20) } & \\
\hline & & Yes & No & Total \\
\hline \multirow{4}{*}{$\begin{array}{c}\text { Franchisor } \\
\text { Brand (Q17) }\end{array}$} & National & $\begin{array}{c}61(\mathrm{R}: 43.3 \%) \\
(\mathrm{C}: 63.9 \%)\end{array}$ & $\begin{array}{l}81 \text { (R: } 56.6 \%), \\
\quad(C: 85.3 \%)\end{array}$ & $143(100 \%)$ \\
\hline & International & $\begin{array}{c}35 \text { (R: } 71.4 \%),(\mathrm{C}: \\
36.1 \%)\end{array}$ & $\begin{array}{c}14 \text { (R: } 28.6 \%),(\mathrm{C}: \\
14.7 \%)\end{array}$ & $49(100 \%)$ \\
\hline & Total & $97(100 \%)$ & $95(100 \%)$ & 192 \\
\hline & \multicolumn{4}{|c|}{ Chi-square, $\mathrm{df}=1: 11.505, \mathrm{p}=.001$} \\
\hline \multicolumn{5}{|c|}{$\mathbf{R}=$ Row percent and $\mathbf{C}=$ Column percent } \\
\hline
\end{tabular}


Table 5

ANOVA Interactions for Ethical Factors by Education/Training, Annual Meetings, and Brand

\begin{tabular}{|c|c|c|c|c|}
\hline Interactions & $\begin{array}{c}\text { Education/ } \\
\text { Training (Q19) } \\
\text { \& Annual Meet- } \\
\text { ing (Q20) }\end{array}$ & $\begin{array}{c}\text { Education/ } \\
\text { Training (Q19) } \\
\text { \& Brand (Q17) }\end{array}$ & $\begin{array}{c}\text { Annual } \\
\text { meeting (Q20) \& } \\
\text { Brand (Q17) }\end{array}$ & $\begin{array}{c}\text { Education/ } \\
\text { Training (Q19) } \\
\text { \& Annual } \\
\text { Meeting Q20) \& } \\
\text { Brand (Q17) }\end{array}$ \\
\hline EIFSB Overall Factor & $\begin{array}{c}F(1,184), p= \\
.011\end{array}$ & Non Sign. & Non Sign. & Non Sign. \\
\hline Factor 1: Ethical Culture & $\begin{array}{c}F(1,184), p= \\
.001\end{array}$ & Non Sign. & $\begin{array}{c}F(1,184), p= \\
.003\end{array}$ & Non Sign. \\
\hline $\begin{array}{l}\text { Factor 2: Information } \\
\text { Integrity }\end{array}$ & $\begin{array}{c}F(1,184), p= \\
.021\end{array}$ & Non Sign. & Non Sign. & Non Sign. \\
\hline $\begin{array}{l}\text { Factor 3: Stakeholder } \\
\text { Relationship }\end{array}$ & Non Sign. & Non Sign. & Non Sign. & Non Sign. \\
\hline $\begin{array}{l}\text { Factor 4: Franchising } \\
\text { Integrity }\end{array}$ & $\begin{array}{c}F(1,184), p= \\
.006\end{array}$ & Non Sign. & Non Sign. & Non Sign. \\
\hline $\begin{array}{l}\text { Factor 5: Franchising } \\
\text { Expansion }\end{array}$ & Non Sign. & Non Sign. & Non Sign. & Non Sign. \\
\hline
\end{tabular}

\section{Franchising Characteristics with Three Levels}

Table 6 presents the analytical results for the franchising characteristics that are measured at three or more levels (i.e., survey questions 16, 15, and 18, in the order they appear in Table 6). For the various groupings of ethical issues vis-à-vis each of the franchising characteristics, Table 6 provides the cell means, the significance level for the Levene test of equality of cell variances, the significance level for the $F$-test in the Oneway ANOVA, Eta2, and a summary statement regarding the significant pair-wise comparisons of cell means. When the Levene test indicates that cell variances are equal $(p>.05)$, Tukey's Honestly Significant Differences (Tukey's HSD) test is an appropriate choice for post hoc mean comparisons. However, when the results of the Levene test indicate unequal cell variances (i.e., $p \leq .05$ ), the Tamhane T2 test is appropriate for post hoc mean comparisons. In Table 6 , the figures in the row labeled ' $p$-value for Levene test' provides the signal as to whether the Tukey HSD test or the Tamhane T2 test is used for the post hoc pair-wise mean comparisons (SPSS, Inc., 2005, pp. 383-385). 
Table 6

Ethical Issues in Franchising Business Success Factors Relative to Franchising Characteristics with Three or More Levels

\begin{tabular}{|c|c|c|c|c|c|c|c|}
\hline $\begin{array}{r}\text { Q 16: Industry/Sector of } \\
\text { Operations: }\end{array}$ & $\mathbf{n}$ & $\begin{array}{l}\text { EIFSB } \\
\text { Overall } \\
\text { Factor }\end{array}$ & $\begin{array}{l}\text { Fac- } \\
\text { tor 1: } \\
\text { Ethical } \\
\text { Culture }\end{array}$ & $\begin{array}{c}\text { Factor } \\
\text { 2: Infor- } \\
\text { mation- } \\
\text { Integrity }\end{array}$ & $\begin{array}{c}\text { Factor } \\
\text { 3: Stake- } \\
\text { holder } \\
\text { Rela- } \\
\text { tionship }\end{array}$ & $\begin{array}{l}\text { Factor } \\
\text { 4: Fran- } \\
\text { chising } \\
\text { Integrity }\end{array}$ & $\begin{array}{c}\text { Factor } \\
\text { 5: Fran- } \\
\text { chising } \\
\text { Expan- } \\
\text { sion }\end{array}$ \\
\hline 1. Apparel-means & 61 & 3.66 & 3.70 & 3.86 & 3.53 & 3.54 & 3.50 \\
\hline 2. Gas Station - means & 39 & 3.51 & 3.30 & 3.86 & 3.37 & 3.64 & 3.47 \\
\hline 3. Jeweler-means & 32 & 3.63 & 3.44 & 3.97 & 3.56 & 3.95 & 3.36 \\
\hline 4. Appliances - means & 19 & 3.69 & 3.82 & 3.84 & 3.37 & 3.39 & 3.76 \\
\hline $\begin{array}{r}\text { 5. Food and Beverages - } \\
\text { Means }\end{array}$ & 34 & 4.03 & 4.14 & 3.90 & 4.01 & 4.13 & 3.87 \\
\hline 6. Sporting (category mean) & 7 & 3.81 & 3.97 & 3.81 & 4.07 & 3.21 & 3.71 \\
\hline$p$-value for Levene test & & .000 & .062 & .000 & .000 & .000 & .000 \\
\hline$p$-value for $F$-test & & .000 & .000 & .949 & .000 & .000 & .000 \\
\hline $\mathbf{E t a}^{2}$ & & $14.92 \%$ & $16.46 \%$ & $.62 \%$ & $11.73 \%$ & $19.79 \%$ & $14.74 \%$ \\
\hline $\begin{array}{r}\text { Significant pair-wise com- } \\
\text { parisons }\end{array}$ & & $\begin{array}{l}5>1 * \\
5>2 * * * \\
5>3 * * \\
6>2 * * *\end{array}$ & $\begin{array}{l}5>1^{*} \\
5>2^{* * *} \\
5>3^{* * *} \\
6>2^{* *} \\
6>3^{*}\end{array}$ & None & $\begin{array}{l}5>2 * * * \\
6>1 * * * \\
6>2^{*} \\
6> \\
3 * * *\end{array}$ & $\begin{array}{l}3>1^{* * *} \\
3>2^{* *} \\
3>4^{* * *} \\
3>6^{* * *} \\
5>1^{* *} \\
5>2^{* *} \\
5> \\
4 * * * \\
5>6^{* *}\end{array}$ & $\begin{array}{l}5>1 * \\
5>2 * * \\
5>3 * * *\end{array}$ \\
\hline $\begin{array}{l}\text { Q 15: Length of Time as } \\
\text { Current Brand Franchisee: }\end{array}$ & $\mathbf{n}$ & $\begin{array}{l}\text { EIFSB } \\
\text { Overall } \\
\text { Factor }\end{array}$ & $\begin{array}{l}\text { Fac- } \\
\text { tor 1: } \\
\text { Ethical } \\
\text { Culture }\end{array}$ & $\begin{array}{l}\text { Factor } \\
\text { 2: Infor- } \\
\text { mation } \\
\text { Integrity }\end{array}$ & $\begin{array}{c}\text { Factor } \\
\text { 3: Stake- } \\
\text { holder } \\
\text { Rela- } \\
\text { tionship }\end{array}$ & $\begin{array}{c}\text { Factor } \\
\text { 4: Fran- } \\
\text { chising } \\
\text { Integrity }\end{array}$ & $\begin{array}{l}\text { Factor } \\
\text { 5: Fran- } \\
\text { chising } \\
\text { Expan- } \\
\text { sion } \\
\end{array}$ \\
\hline 1. 1 to 2 Years - means & 52 & 3.85 & 3.81 & 4.17 & 3.76 & 3.82 & 3.61 \\
\hline 2. 3 to 5 Years - means & 77 & 3.68 & 3.61 & 3.88 & 3.62 & 3.78 & 3.49 \\
\hline 3. 6 Years or More - means & 63 & 3.60 & 3.64 & 3.65 & 3.43 & 3.53 & 3.64 \\
\hline$p$-value for Levene test & & .376 & .706 & .028 & .265 & .021 & .586 \\
\hline$p$-value for $F$-test & & .001 & .259 & .000 & .035 & .015 & .110 \\
\hline Eta $^{2}$ & & $5.14 \%$ & $1.42 \%$ & $12.90 \%$ & $3.48 \%$ & $4.36 \%$ & $2.31 \%$ \\
\hline
\end{tabular}


Table 6 (continued)

\begin{tabular}{|c|c|c|c|c|c|c|c|}
\hline $\begin{array}{r}\text { Significant pair-wise com- } \\
\text { parisons }\end{array}$ & & $1>3 * *$ & None & $\begin{array}{l}1> \\
2 * * * \\
1>3^{* * *}\end{array}$ & $1>3 *$ & $1>3 *$ & None \\
\hline $\begin{array}{l}\text { Q 18: Length of Current } \\
\text { Franchising Agreement: }\end{array}$ & $\mathbf{n}$ & $\begin{array}{l}\text { EIFSB } \\
\text { Overall } \\
\text { Factor }\end{array}$ & $\begin{array}{l}\text { Fac- } \\
\text { tor 1: } \\
\text { Ethical } \\
\text { Culture }\end{array}$ & $\begin{array}{c}\text { Factor } \\
\text { 2: Infor- } \\
\text { mation } \\
\text { Integrity }\end{array}$ & $\begin{array}{c}\text { Factor } \\
\text { 3: Stake- } \\
\text { holder } \\
\text { Rela- } \\
\text { tionship }\end{array}$ & $\begin{array}{l}\text { Factor } \\
\text { 4: Fran- } \\
\text { chising } \\
\text { Integrity }\end{array}$ & $\begin{array}{l}\text { Factor } \\
\text { 5: Fran- } \\
\text { chising } \\
\text { Expan- } \\
\text { sion }\end{array}$ \\
\hline 1. 1 to 2 Years - means & 25 & 3.45 & 3.19 & 3.95 & 3.32 & 3.50 & 3.44 \\
\hline 2. 3 to 5 Years - means & 86 & 3.68 & 3.69 & 3.87 & 3.52 & 3.63 & 3.56 \\
\hline 3. 6 Years or More - means & 81 & 3.79 & 3.81 & 3.88 & 3.75 & 3.85 & 3.62 \\
\hline$p$-value for Levene test & & .015 & .302 & .000 & .010 & .000 & .000 \\
\hline$p$-value for $F$-test & & .002 & .000 & .823 & .010 & .010 & .238 \\
\hline Eta $^{2}$ & & $6.23 \%$ & $7.73 \%$ & $.21 \%$ & $4.75 \%$ & $4.74 \%$ & $1.51 \%$ \\
\hline $\begin{array}{r}\text { Significant pair-wise com- } \\
\text { parisons }\end{array}$ & & $\begin{array}{l}2>1 * \\
3>1 * * *\end{array}$ & $\begin{array}{l}2>1 * \\
3>1 * *\end{array}$ & None & $3>1 * * *$ & $3>1 *$ & None \\
\hline$* p \leq .05 ; * * p \leq .01 ; * * * p \leq .001$ & & & & & & & \\
\hline
\end{tabular}

As shown in Table 6, a significant effect for the independent variable of 'industry/sector of operations' occurs for the Overall Factor and for all Factors except Franchising Integrity (Factor 2). In each case the significant effect is quite substantial, as indicated by Eta 2 which measures the proportion of variance in the dependent variable that is explained by the independent variable (Hair et al., 2010). Across the significant relationships, Eta2 ranged from $11.73 \%$ to $19.79 \%$. Ethical issues in general (the Overall Factor) are significantly more important for food and beverages franchisees than for apparel, gas station, and jeweler franchisees; and for sporting franchisees than for gas station franchisees. Ethical issues concerning the development and maintenance of the Ethical Culture for franchising (Factor 1) are significantly more important for food and beverages franchisees than for apparel, gas station, and jeweler franchisees; and for sporting franchisees as opposed to gas station and jeweler franchisees. The importance of ethical issues concerning the Franchising Integrity (Factor 2) does not differ significantly across the categories of industry/sector of operations. Ethical issues concerning the franchising system's key Stakeholder Relationship (Factor 3) are significantly more important in the food and beverages category than in the gas stations category; and in the sporting category, than in the apparel, gas station, and jeweler categories. Ethical issues concerning the franchising System Integrity (Factor 4) are more important for jeweler franchisees than for apparel, gas station, appliances, and sporting franchisees; and for food and beverages franchisees relative to apparel, gas station, appliances, and sporting franchisees. Ethical issues concerning Franchising Expansion opportunities 
(Factor 5) are significantly more important for food and beverages franchisees than for apparel, gas station, and jeweler franchisees.

Also as indicated in Table 6, a significant effect for the independent variable 'length of time as a current brand franchisee' exists for the Overall Factor and for the factors of Franchising Integrity (Factor 2), Stakeholder Relationships (Factor 3), and System Integrity (Factor 4), but not for factors of Information Integrity (Factor 2) and Franchising Expansion (Factor 5). The magnitude of the significant effect, as indicated by Eta2, ranges from $3.48 \%$ to $12.90 \%$. Ethical issues in general (Overall Factor) and ethical issues concerning the Information Integrity; (Factor 2), the franchising system's key Stakeholder Relationships (Factor 3), and the System Integrity (Factor 4) are significantly more important for franchisees who have been with the current brand for six years or more than for franchisees who are new to the brand (i.e., 1 to 2 years). In addition, ethical issues concerning Information Integrity (Factor 2) are significantly more important to franchisees with three to five years of experience with the brand as opposed to franchisees who have relatively little experience with the brand (i.e., 1 to 2 years).

Finally, a significant effect for 'length of the current franchising agreement' exists relative to the Overall Factor and Ethical Culture (Factor 1), Stakeholder Relationships (Factor 3), and System Integrity (Factor 4), but not for factors of Information Integrity (Factor 2) and Franchising Expansion (Factor 5). As indicated by Eta2, the 'length of the current franchising agreement' explains between $4.74 \%$ and $7.73 \%$, depending on which significant relationship is being considered. Ethical issues in general (the Overall Factor) and ethical issues concerning the development and maintenance of Ethical Culture for franchising (Factor 1) are significantly more important for franchisees with longer term franchising agreements (i.e., three to five years or six years or more) than for franchisees with shorter agreements (i.e., one to two years). Moreover, ethical issues concerning Stakeholder Relationships (Factor 3) and ethical issues concerning Franchising Integrity (Factor 4) are significantly more important to franchisees with the longest contractual agreements (i.e., six years or more) than to those with the shortest franchising contracts (i.e., one to two years).

\section{Discussion and Implications}

This study sought to determine whether or not these clusters of ethical issues are connected in any systematic fashion to six different franchising characteristics. The results for franchising characteristics with two-levels of measurement show that whether or not franchisees receive education/training from the franchisor has a very strong influence on the various groups of ethical issues, whether or not there is an annual meeting with the franchisor to discuss franchising issues has a small influence, and whether or not the brand is national or international has a very small influence. Also, the results for the three franchising characteristics with three or more measurement levels clearly support the notion that these characteristics do influence the clusters of Ethical Issues in Franchising Business Success. 
The significant differences in Table 3 for five of six mean comparisons for the education/training variable, 2 of 6 comparisons for the annual meeting variable, and 1 of 6 comparisons for international versus national franchising brand show that Ethical Issues in Franchising Business Success are significantly more important to those franchisees having closer contact with the franchisor. Receiving education/training from the franchisor upon signing a franchising agreement and having an annual meeting with the franchisor to discuss franchising issues apparently promotes and reinforces the importance of ethical issues in franchising. These findings have some managerial implications for building successful franchising businesses. One implication is that franchisors must provide education and training to the new franchisees when entering into a franchising agreement. This could eliminate any potential confusion and/or uncertainty that new franchisees might have about their responsibilities and rights under the franchising agreement. In turn, this could establish a mutual trust between the franchisor and franchisee which is essential for the success of the franchising relationship. The second implication is that the initial education and training could be a key for open and effective future communications between the parties. Also, since having an annual meeting is significant for Information Integrity (Factor 2) and System Integrity (Factor 4), a regular annual meeting between franchisors and franchisees appears to be crucial for maintaining the integrity of franchising information and the franchising system. The implication is that the annual meeting may help to avoid any future potential conflicts. Moreover, concerning the franchise brand, international brands value the protection and expansion of franchising business opportunities more than national brands. This is understandable for the fact that, as they expand to new markets, international brands might be concerned about protecting their businesses.

In addition, the results in Table 4 show the significant associations between education/training, an annual meeting, and franchisor brand, which further support the above implications. More specifically, the results suggest that: (1) franchisors who offer initial education/training have more annual meetings than those franchisors who do not offer initial education/training; (2) international franchisor brands offer initial education/ training more often than national brands; and (3) international franchisors are more likely to have annual meetings than national franchisors. Also, since there are significant interaction effects between education/training and the annual meeting for the Overall Factor, Ethical Culture (Factor 1), Information Integrity (Factor 2) and System Integrity (Factor 4) in Table 5, these findings further emphasize the importance of having initial education/training and regular annual meetings for the long-term success of the franchising business. These findings suggest that in order for franchisors and franchisees to reduce any potential ethical conflicts between them that could adversely impact the success of the franchising business, there must be both initial education and training on these ethical issues and annual meetings to reinforce their roles and responsibilities for the successful business relationships.

Concerning the 'industry/sector of operations' in Table 4, ethical issues seem to be much more important to food and beverages franchisees than to any of the other types of franchising businesses; 14 of the 24 significant pair-wise comparisons identify ethical 
issues in the food and beverages category as being significantly more important than in the relevant comparison categories. This study was not designed to address why ethical issues are more important for some business categories than others. Rather, it was designed to investigate if they were perceived as more important by some business categories than other groups; thus, the results must be interpreted accordingly. Of the remaining 10 significant pair-wise comparisons for the 'industry/sector of operations,' selected ethical issues are significantly more important in the sporting category as opposed to the comparison group in six cases, and ethical issues are significantly more important in the jeweler category in four cases. The significant differences involving the sporting category should be interpreted with appropriate caution, however. There are 7 respondents in the sporting category; thus there may be some bias that has been introduced by the small size of this group relative to the others. Given the nature of the franchising businesses covered in this study, the sporting group could not be combined with any of the other groups. Where the industry findings indicate that certain ethical issues are more important for a successful long-term franchising relationship, franchisors and franchisees in these industries, especially in the food and beverage industry, must be aware of these ethical issues as potential sources of conflict. They must also be aware that if these ethical issues are not addressed, they could adversely affect the long-term success of the franchising business.

For the independent variable 'length of time as a current brand franchisee,' the ethical issues identified in the Overall Factor and in the Factors of Information Integrity (Factor 2); the key Stakeholder Relationships (Factor 3); and the System Integrity (Factor 4) are significantly more important for longer-term brand franchisees than for shorter-term brand franchisees. Apparently, those franchisees with the most experience with a brand are the most concerned about having fair and just dealings with relevant stakeholders on many ethical issues. This is a perspective that evolves over time, perhaps as the franchisees come to better understand and embrace the importance of all stakeholders in producing long-term success. Also, over time and with greater experience, the franchisor/franchisee relationship becomes more stable and sustainable, thereby enabling franchisees to devote more attention and energy to a variety of ethical issues. This suggests that franchisors must provide more support and help through education and training upon signing an agreement, and by having annual meetings.

As for 'length of the current franchising agreement, 'those franchisees having longer franchising agreements, in general attribute greater importance to the various Ethical Issues in Franchising Business Success than do those franchisees having shorter franchising agreements. Perhaps a longer-term franchise agreement raises the stakes for both franchisors and franchisees to such an extent that effectively dealing with ethical issues becomes more important. Ethically questionable decisions and actions might permit a franchising business to survive in the short term, but such behavior would very likely be detrimental in the long term. Again, given the strong importance of initial education and training, and the somewhat lesser importance of having an annual meeting for the long-term success of the franchising relationships, franchisors could implement more intense initial and follow up education and training programs, as well as conducting an- 
nual meetings to address the franchisees' concerns about these ethical issues before they become a debilitating conflict that undermines the success of the franchising operation.

\section{Strategic Implications for the Related Parties}

These findings have strategic implications for franchisors and franchisees. First, since the results show that initial education and training is very important for ethical issues, franchisors must make sure that they offer, and franchisees request, extensive education and training about all facets of the franchising system. This education and training would set proper expectations from the start for both franchisors and franchisees to establish trust and commitment for successful relationships between the parties (Gamez and Gonzalez, 2010: Rahatullah and Raeside, 2008). Second, franchisors must have mandatory annual meetings with franchisees in order to discuss the current and future concerns/issues that could lead to potential conflicts between the parties. These annual meetings could reinforce and/or create a greater awareness of the roles in their relationships that, as suggested by Weaven et al. (2010), may assist the franchisors and franchisees to develop levels of trust and commitment for the long-term success of the franchising relationships. Third, the results indicate that local franchisors must offer initial education and training to their new franchisees and also have annual meetings in order to compete successfully with international franchisors. It is important to note that the local franchisors must have both initial education/training and annual meetings to compete against international franchisors. Fourth, it seems that franchisors in food and beverage industries are likely to have significantly more concerns for ethical issues than other industries. Therefore, the franchisors in this industry might be more conscious of ethical issues that may result in conflicts. This may be avoided by offering appropriate initial education/training and having regular annual meetings. Finally, the results concerning the length of time indicate that creating a successful franchising business takes a long time. Therefore, both franchisors and franchisees must work together to develop mutual trust and commitment for the long term success of the franchising business. In summary, our key findings suggest that in order to avoid potential conflicts and have a successful long-term franchising business, there must be an appropriate and effective initial education and training upon signing an agreement, and further there must be annual meetings.

\section{Limitations of the Study}

Although this study provides important insights into (a) the franchisees' perceptions of ethical issues that influence the long-term success of the franchising system and (b) the impacts of various franchising characteristics on those perceptions, the study does have some limitations. The first limitation is that the study examined ethical issues only from the perspective of the franchisees. While the results are useful, there is no information about franchisors' perceptions regarding the importance of these ethical issues for the long-term success of the franchising system. Therefore, future research should include the franchisors' perspectives of the ethical issues in order to compare both 
perspectives and to address the ethical concerns of both parties for mutually beneficial solutions to those concerns. The second limitation is that the sample was restricted to two cities in Turkey. A sample covering franchisees in more than two Turkish cities could be more representative of the franchisees in Turkey; thus, future research should include franchisees from more cities to improve the generalizability of the results. The third limitation of the study is that it was conducted only with Turkish franchisees. The same survey should be extended beyond the current sample from Turkey. Studying franchisees in other nations would be useful in understanding any potential effect of different cultures on these ethical issues. Given the globalization of franchising businesses, understanding ethical issues in different cultural contexts and the potential effects of franchising characteristics on these ethical issues could contribute to the global success of franchising systems.

\section{References}

Amos, J.H. (2001). "Franchising, More than Any Act of Government, Will Strengthen the Global Economy," Franchising World, 33(4): 8.

Aydın, M. (2008). UFRAD, Hurriyet Newspaper, November 11, 2008.

Ball, Jr., D.A., Wendell, H., McCulloch, P.L., Frantz, J., Geringer, M., and Minor, M.S. (2002).

International Business: The Challenge of Global Competition (8th ed.), New York: McGraw-Hill Irwin.

Bass, B.M., Cascio, W.F., and O’Connor, E.J. (1974). "Magnitude Estimations of Expressions of Frequency and Amount," Journal of Applied Psychology, 59(3): 313-320.

Chapman, P. (1997). "Life-Saver in a Perilous Sea of Job Losses (Future of Franchising in Europe)," The European, October 9: 39.

Cochet, O., Dormann, J., and Ebrmann, T. (2008). "Capitalizing on Franchise Autonomy: Relational Forms of Governance as Controls in Idiosyncratic Franchise Dyads," Journal of Small Business Management, 46(1): 50-72.

Dant, R.P. (2008). "A Futuristic Research Agenda for the Field of Franchising," Journal of Small Business Management, 46(1): 91-98.

Davies, M.A.P, Lassar, W., Manolis, C., Prince, M. and Winsor, R.D. (2011). “A Model of Trust and Compliance in Franchise Relationships," Journal of Business Venturing, 26(3): 321-340.

Doherty, A.M. and Alexander, N. (2006), "Power and Control in International Retail

Franchising," European Journal of Marketing, 40(11/12): 1292-1316.

Doherty, A.M. and Quinn, B. (1999). "International Retail Franchising: An Agency Theory

Perspective,” International Journal of Retail \& Distribution Management. 27(6): 224-266.

Elango, B. and Fried, V.H. (1997). "Franchising Research: A Literature Review and Synthesis," Journal of Small Business Management, 35(3): 68-81.

Eser, Z. (2012). "Inter-organizational Trust in Franchise Relationships and the Performance Outcomes: The Case of Fast-food Restaurants in Turkey," International Journal of Contemporary Hospitality Management, 24(5) 774-790. 
Gamez-Gonzalez, J., Rondan-Cataluna, F.J., Navaro-Garcia, A., and Diez-de Castro, E.C. (2010.’Towards an International Code of Franchising," Management Decision, 48 (10):1568-1995.

Grunhagen, M. and Mittelstaedt R.A. (2005). "Entrepreneurs or Investors: Do Multi-unit Franchisees Have Different Philosophical Orientations?” Journal of Small Business Management, 43(3): 207-225.

Hall, P. and Dixon, R. (1988). Franchising. London: Pitman Publishing.

Hair, Jr., J.F., Black, W.C., Babin, B.J., and Anderson, R.E. (2010). Multivariate Data Analysis with Readings, New Jersey: Prentice Hall.

Hoffman, R.C. and Preble, J.F. (2004). “Global Franchising: Current Status and Future

Challenges," Journal of Services Marketing, 18 (2): 101-113.

Kaptein, M. and Schwartz, M.S. (2008). "The Effectiveness of Business Codes: A Critical Examination of Existing Studies and Development of an Integrated Research Model," Journal of Business Ethics, 77(2) 111-127.

Kaufmann, P., and Dant, R.P. (2001). "The Pricing of Franchise Rights," Journal of Retailing, 77: $537-545$.

Kumkale, R. (2006). Franchising, http://www.alomaliye.com (retrieved on August 4, 2010).

Lal, R. (1990). "Improving Channel Coordination Through Franchising," Marketing Science, 9(4): 299-318.

Larson, P. (2002). “International Growth Patterns Remain Strong,” Franchising World, April:608.

Peterson, A. and Dant, R.P. (1990). "Perceived Advantage of the Franchise Option from the Franchise Perspective: Empirical Insights from a Service Franchise," Journal of Small Business Management, 28(3): 46-61.

Preble, J.F. and Hoffman, R.C. (1999). "The Nature of Ethics Codes in Franchise Associations Around the Globe," Journal of Business Ethics, 18: 239-253.

Quinn, B., and Doherty, A.M. (2000). "Power and Control in International Retail Franchise: Evidence from Theory and Practice," International Marketing Review, 17(4/59): 354-372.

Rahatullah, M.K. and Raeside, R. (2008). "Towards Operational Excellence in Franchising: Achieving Synergy, Adding Value, and Security Competitive Advantage by Exploiting Entrepreneurial Traits and Core Competencies," S.A.M. Advanced Management Journal, 73(3): 25-38.

Rondan-Cataluna, F. J., Navarro-Garcia, A., Gamez-Gonzalez, J. and Rodriguez-Rad, C. J. (2012). "Content Analysis and Assessment of International Codes of Franchising Association," Management Decision, 50(4) 635-650

Shane, S.A. (1996). "Why Franchise Companies Expand Overseas," Journal of Business Venturing, 11(2) 73-88.

Storholm, G. and Scheuing, E. (1994). "Ethical Implications of Business Format Franchising," Journal of Business Ethics, 13: 181-188.

SPSS, Inc. (2005). “Oneway ANOVA,” SPSS Base 14.0 User's Guide: 379-387. Chicago, IL: SPSS Inc.

Swartz, L.N. (2001). "Franchising Successfully Circles the Globe," in D. Welsh and I. Alon (eds.), International Franchising in Emerging Markets: Central and Eastern Europe and Latin America: 43-61. CCH, Chicago, IL

Thorelli, H.B. (1986). “Networks: between Markets and Hierarchies,” Strategic Management Journal,.7(1): 37-51. 
UFRAD - National Franchising Organization (2010a). Available [online] at: http://www.ufrad.org.tr (retrieved on August 19, 2010).

------, (2010b). Personal communication, October 8, 2010.

Weaven, S. and Frazer L. (2003). "Predicting Multiple Unit Franchising: A Franchisor and Franchisee Perspective," Journal of Marketing Channels, 10(3/4): 53-82.

Weaven, S., Frazer, L. and Giddings, J. (2010). "New Perspectives on the Causes of Franchise Conflict in Australia," Asian Pacific Journal of Marketing and Logistics, 22(2): 135-155.

Welsh, D., Alon, I., and Falbe, C.M. (2006). "An Examination of International Retail Franchising in Emerging Markets,” Journal of Small Business Management, 44(1): 130-150. 


\section{Appendix A: Survey of Ethical Issues in Franchise Business Success}

Please indicate how important you consider each of the following issues to be in promoting and protecting the interests of both franchisor and franchisee to ensure long-term success of the franchising business.

1. Pursuing dual distribution opportunities for the franchisor to increase sales for the franchising business.

$$
\begin{array}{lll}
\mathbf{0} \text { = not important at all. } & \mathbf{1} \text { = slightly important. } & \mathbf{2} \text { = important to some degree. } \\
\mathbf{3} \text { = moderately important. } & \mathbf{4} \text { = very important. } & \mathbf{5} \text { = extremely important } .
\end{array}
$$

\section{Note: Questions 2 through 14 use the same response scale as appears underneath Question 1.}

2. Providing full and accurate disclosure of information when selling a franchise and after the franchising agreement is signed.

3. Providing a notice and process for dealing with disputes, terminations, or expirations of agreements.

4. Maintaining the integrity and reputation of the franchise concept or system.

5. Avoiding questionable use of advertising payments and/or having no false or misleading advertising.

6. Having a franchise agreement that seems to protect the franchisor more than the franchisee.

7. Protecting trade secrets or proprietary information and not releasing proprietary information to outside parties.

8. Complying with all applicable laws.

9. Having fair dealings between franchisor and franchisee.

10. Providing open and effective two-way communication among all parties.

11. Providing a quality product or service in line with the image of the franchising business.

12. Practicing non-discrimination and affirmative action regarding all parties.

13. Safeguarding the public interest.

14. Having a general statement promoting ethical principles that are consistent with the image of the franchising business.

\section{Characteristics of Franchise Businesses:}

15. How long have you been a franchisee of this Brand?

$$
\text { 1-2 _ 3-5 years _ 6-10 years _ More than } 10 \text { years }
$$

16. Please indicate the industry / sector you are operating in

17. Your franchisor brand is: National _ or International

18. How long is your current franchising agreement? 1-2 _ 3-5 years _ 6-10 years _ More than 10 years

19. When you signed the franchising agreement, did you go through any education or training? Yes _ No

20. Do you have an annual meeting with the franchisor to discuss the general franchising issues? Yes _ No _ 